\title{
Effect of heat stress during the dry period on mammary gland development
}

\author{
S. Tao, J. W. Bubolz, B. C. do Amaral, ${ }^{1}$ I. M. Thompson, M. J. Hayen, S. E. Johnson, and G. E. Dahl ${ }^{2}$ \\ Department of Animal Sciences, University of Florida, Gainesville 32611
}

\begin{abstract}
Heat stress during the dry period negatively affects hepatic metabolism and cellular immune function during the transition period, and milk production in the subsequent lactation. However, the cellular mechanisms involved in the depressed mammary gland function remain unknown. The objective of the present study was to determine the effect of heat stress during the dry period on various indices of mammary gland development of multiparous cows. Cows were dried off approximately $46 \mathrm{~d}$ before expected calving and randomly assigned to 2 treatments, heat stress ( $\mathrm{HT}, \mathrm{n}=15)$ or cooling $(\mathrm{CL}, \mathrm{n}=14)$, based on mature equivalent milk production. Cows in the CL treatment were provided with sprinklers and fans that came on when ambient temperatures reached $21.1^{\circ} \mathrm{C}$, whereas $\mathrm{HT}$ cows were housed in the same barn without fans and sprinklers. After parturition, all cows were housed in a freestall barn with cooling. Rectal temperatures were measured twice daily (0730 and $1430 \mathrm{~h}$ ) and respiration rates recorded at $1500 \mathrm{~h}$ on a Monday-Wednesday-Friday schedule from dry off to calving. Milk yield and composition were recorded daily up to $280 \mathrm{~d}$ in milk. Daily dry matter intake was measured from dry off to $42 \mathrm{~d}$ relative to calving. Mammary biopsies were collected at dry off, $-20,2$, and $20 \mathrm{~d}$ relative to calving from a subset of cows (HT, $\mathrm{n}=7$; CL, $\mathrm{n}=7$ ). Labeling with Ki67 antigen and terminal deoxynucleotidyl transferase deoxyuridine triphosphate nick-end labeling were used to evaluate mammary cell proliferation and apoptosis, respectively. The average temperature-humidity index during the dry period was 76.6 and not different between treatments. Heat-stressed cows had higher rectal temperatures in the morning $\left(38.8\right.$ vs. $\left.38.6^{\circ} \mathrm{C}\right)$ and afternoon $\left(39.4\right.$ vs. $\left.39.0^{\circ} \mathrm{C}\right)$, greater respiration rates (78.4 vs. 45.6 breath/min), and decreased dry matter intake ( 8.9 vs. $10.6 \mathrm{~kg} / \mathrm{d}$ ) when dry compared with CL cows. Relative to HT cows, CL cows had greater milk production (28.9 vs. $33.9 \mathrm{~kg} / \mathrm{d}$ ), lower milk protein concentration (3.01 vs. $2.87 \%$ ), and tended to have lower
\end{abstract}

Received March 2, 2011.

Accepted September 16, 2011.

${ }^{1}$ Current address: Vita Plus Corporation, Madison, WI.

${ }^{2}$ Corresponding author: gdahl@ufl.edu somatic cell score (3.35 vs. 2.94) through $280 \mathrm{~d}$ in milk. Heat stress during the dry period decreased mammary cell proliferation rate (1.0 vs. $3.3 \%$ ) at $-20 \mathrm{~d}$ relative to calving compared with CL cows. Mammary cell apoptosis was not affected by prepartum heat stress. We conclude that heat stress during the dry period compromises mammary gland development before parturition, which decreases milk yield in the next lactation.

Key words: heat stress, dry period, mammary gland, epithelial cell

\section{INTRODUCTION}

The dry period in dairy cattle is critical for maximal milk production in the subsequent lactation, as its absence is associated with a significant decrease in milk yield (Bachman and Schairer, 2003; Grummer and Rastani, 2004). During the dry period, mammary tissue undergoes extensive growth and cell turnover (Capuco et al., 1997; Sorensen et al., 2006). This process is necessary to compensate for mammary cell loss during the previous lactation (Capuco et al., 2001) and to replace senescent secretory epithelial cells (Capuco et al., 1997). Because the lactation curve is a function of mammary cell number and secretory capacity per cell (Capuco et al., 2003), any manipulation during the dry period that enhances mammary growth may be a promising approach to improve lactation performance in dairy cows.

Environmental factors, such as photoperiod and temperature, can be manipulated during the dry period and influence a cow's performance in the subsequent lactation. Cows exposed to short-day photoperiod (SDPP) when dry produce more milk in the next lactation (Miller et al., 2000; Auchtung et al., 2005) and have improved immune function (Auchtung et al., 2004) compared with cows under a long-day photoperiod (LDPP). Short days also enhance mammary gland remodeling through increased mammary cell proliferation and decreased epithelial cell apoptosis relative to LDPP (Wall et al., 2005). This increased mammary growth occurs during a specific window of the dry period (i.e., 3-6 wk before calving; Wall et al., 2005). Strong evidence exists that the observed photoperiodic effects are related to altered prolactin (PRL) signaling (Dahl, 2008), particularly the inverse relationship 
between circulating PRL and PRL-receptor (PRL-R) expression in multiple tissues. Indeed, SDPP decreases circulating PRL concentrations and increases PRL$\mathrm{R}$ gene expression in immune cells (Auchtung et al., 2005), hepatic tissue (Auchtung et al., 2003), and the mammary gland (Auchtung et al., 2005) compared with LDPP.

Heat stress is another environmental factor that can affect cow productivity. For example, heat stress in lactating cows is detrimental to milk production and reproductive performance (West, 2003; Collier et al., 2006). Moreover, heat stress during the dry period has a tremendous carryover effect into the postpartum period. In addition to decreased milk production (Wolfenson et al., 1988; Avendaño-Reyeset al., 2006; do Amaral et al., 2009), heat stress during the dry period negatively affects hepatic metabolism in early lactation, which compromises the transition into lactation from the nonlactating state (do Amaral et al., 2009). Immune function also is decreased by heat stress during the transition period. Relative to heat stress, cooled dry cows have greater lymphocyte proliferation (do Amaral et al., 2010), neutrophil phagocytosis and oxidative burst, as well as IgG production against ovalbumin (do Amaral et al., 2011). Similar to photoperiod, heat stress during the dry period increases circulating PRL concentrations (do Amaral et al., 2009) and decreases PRL-R gene expression in lymphocytes (do Amaral et al., 2010) and hepatic tissue (do Amaral et al., 2009) compared with heat stress abatement. However, studies related to effects of heat stress on mammary gland growth and development are limited. Adin et al. (2009) concluded that cows cooled during the dry period had greater mammary epithelial cell proliferation during the close-up period based on increased expression of the hormone-sensitive lipase gene in the mammary gland compared with non-cooled cows. But the gene expression profile of a lipid synthetic pathway is more associated with cell secretory state rather than mammary gland growth. Our hypothesis was that heat stress during the dry period compromised mammary gland growth compared with heat stress abatement, and thus decreased subsequent milk yield. Therefore, the objective of the current study was to directly evaluate the effect of heat stress during the dry period on mammary gland development of dairy cows.

\section{MATERIALS AND METHODS}

\section{Animals, Housing, and Experimental Design}

This study was conducted at the Dairy Unit of University of Florida (Hague, Florida) from May to November, 2009. All of the treatments and procedures were approved by the University of Florida Institute of Food and Agricultural Sciences Animal Research Committee. All cows were dried off at approximately 46 $\mathrm{d}$ relative to expected calving by cessation of milking and intramammary infusion with antibiotic (Quartermaster; Pfizer Animal Health, Kalamazoo, MI) to each quarter. At dry off, cows were assigned randomly to 1 of 2 treatments: heat stress $(\mathbf{H T}, \mathrm{n}=15)$ or cooling $(\mathbf{C L}, \mathrm{n}=14)$, based on mature equivalent milk production from the previous lactation. Parity between HT and CL cows $(1.6 \pm 0.3$ vs. $1.9 \pm 0.3$, respectively; $P=$ $0.5)$ was similar.

Dry cows were housed in a sand-bedded freestall barn with the stall areas for CL cows equipped with sprinklers (Rain Bird Manufacturing, Glendale, CA) and fans (J\&D Manufacturing, Eau Claire, WI), whereas those of the HT cows were not. When ambient temperature exceeded $21.1^{\circ} \mathrm{C}$, fans automatically turned on and sprinklers were activated for $1.5 \mathrm{~min}$ at 6 -min intervals. Photoperiod (14 h light:10 h dark) of the barn for dry cows on both treatments was controlled using metal halide lights. The lights provided approximately 250 lx intensity at eye level of cows and were kept on from 0600 to $2000 \mathrm{~h}$. After calving, all cows were housed in the same sand-bedded freestall barn with sprinklers and fans for cooling.

Air temperature and relative humidity of each pen in the barn for dry cows were recorded every $15 \mathrm{~min}$ by Hobo Pro series Temp probes (Onset Computer Corp., Pocasset, MA). The temperature-humidity index (THI) was calculated based on the equation reported by Dikmen et al. $(2008)$ : THI $=(1.8 \times \mathrm{T}+$ $32)-[(0.55-0.0055 \times \mathrm{RH}) \times(1.8 \times \mathrm{T}-26)]$, where $\mathrm{T}=$ air temperature $\left({ }^{\circ} \mathrm{C}\right)$ and $\mathrm{RH}=$ relative humidity (\%). During the dry period, rectal temperatures were measured twice daily (0730 and $1430 \mathrm{~h}$ ) using a GLA M700 digital thermometer (GLA Agricultural Electronics, San Luis Obispo, CA) and respiration rate was measured by counting the flank movements for $1 \mathrm{~min}$ in the afternoon $(1500 \mathrm{~h})$ three times weekly (Monday-Wednesday-Friday). Dry cows were fed once per day $(0900 \mathrm{~h})$ and milking cows were fed twice daily (0800 and $1300 \mathrm{~h}$ ). The diet composition for both the prepartum and postpartum periods is given in Table 1 . Estimates of DMI were recorded from dry off until 42 d postpartum using the Calan gate system (American Calan Inc., Northwood, NH). Daily water consumption for each pen was recorded during the dry period and water intake for individual cow per day was estimated by dividing water consumption by number of cows in each pen. Cows were milked twice daily (0800 and 2000 h) and milk production was recorded daily up to 280 DIM. Cows were weighed and body condition scored at dry off, $-32,-18,0,14,28$, and $42 \mathrm{~d}$ relative to 
Table 1. Ingredient composition of TMR for cows in both prepartum and postpartum period

\begin{tabular}{lcc}
\hline $\begin{array}{l}\text { Ingredient, } \\
\% \text { of DM }\end{array}$ & Prepartum & Postpartum \\
\hline Corn silage & 37 & 40.93 \\
Sorghum silage & 25 & - \\
Alfalfa hay & - & 8.05 \\
Wet brewers grain & - & 5.56 \\
Distillers grain & 5 & 6.98 \\
Corn meal & 11 & 18.28 \\
Soybean meal & 11 & 5.26 \\
Citrus pulp & 5 & 7.18 \\
Soy plus & - & 4.02 \\
Mineral and vitamin mix ${ }^{1}$ & 6 & 3.73 \\
\hline
\end{tabular}

${ }^{1}$ The mineral and vitamin mix prepartum included $21 \% \mathrm{CP}, 2 \%$ crude fat, $13 \%$ crude fiber, $8.5 \% \mathrm{Ca}, 1 \% \mathrm{P}, 3 \% \mathrm{NaCl}, 3.5 \% \mathrm{Mg}, 4.4 \% \mathrm{~S}, 34$ $\mathrm{mg}$ of $\mathrm{Co} / \mathrm{kg}, 129 \mathrm{mg}$ of $\mathrm{Cu} / \mathrm{kg}, 15 \mathrm{mg}$ of I $/ \mathrm{kg}, 300 \mathrm{mg}$ of $\mathrm{Mn} / \mathrm{kg}, 7$ $\mathrm{mg}$ of Se/kg, $435 \mathrm{mg}$ of $\mathrm{Zn} / \mathrm{kg}, 200 \mathrm{mg}$ of $\mathrm{F} / \mathrm{kg}, 220,459 \mathrm{IU}$ of vitamin $\mathrm{A} / \mathrm{kg}, 70,000 \mathrm{IU}$ of vitamin $\mathrm{D}_{3} / \mathrm{kg}$, and 5,512 IU of vitamin $\mathrm{E} / \mathrm{kg}$. The mineral and vitamin mix postpartum included $25 \% \mathrm{CP}, 0.25 \%$ crude fat, $1 \%$ crude fiber, $3 \% \mathrm{ADF}, 5.75 \% \mathrm{Ca}, 1.2 \% \mathrm{P}, 4.75 \% \mathrm{NaCl}, 9.25 \mathrm{mg}$ of $\mathrm{Se} / \mathrm{kg}, 110,230 \mathrm{IU}$ of vitamin $\mathrm{A} / \mathrm{kg}, 39,683 \mathrm{IU}$ of vitamin $\mathrm{D}_{3} / \mathrm{kg}$, $1,102 \mathrm{IU}$ of vitamin $\mathrm{E} / \mathrm{kg}$, and $381 \mathrm{mg}$ of monensin $/ \mathrm{kg}$.

calving before feeding when dry and after morning milking during lactation. Prepartum cumulative BW and BCS change were calculated by subtracting values at -32 and $-18 \mathrm{~d}$ relative to calving and calving from values at dry off. Postpartum cumulative BW and BCS change were calculated by subtracting values at 14,28 , and $42 \mathrm{~d}$ relative to calving from values at calving.

\section{Milk Composition}

Percentages of milk fat, protein, lactose, and SCC were measured at each milking by AfiLab real time milk analyzer (SAE Afikim, Kibbutz Afikim, Israel) until 280 DIM. The AfiLab milk analyzer is based on the optical characteristics of light scattering off matter such as milk fat and protein, among others. The values obtained using AfiLab are well correlated with DHIA measures (De Vries et al., 2009). Somatic cell score was calculated based on the equation SCS = $\left[\log _{10}(\mathrm{SCC} / 12.5)\right] / \log _{10}(2)$.

\section{Blood Sampling and Hormone Analysis}

Blood samples for PRL analysis were collected once daily $(0745 \mathrm{~h})$ at dry off, $-32,-18$, and $-7 \mathrm{~d}$ relative to calving. Blood was collected from coccygeal vessels into sodium-heparinized Vacutainers (Becton, Dickinson and Co., Franklin Lakes, NJ). Samples were immediately placed in ice and centrifuged at 2,619 $\times g$ at $4^{\circ} \mathrm{C}$ for 30 min within $1 \mathrm{~h}$ after collection. After centrifugation, plasma samples were frozen at $-20^{\circ} \mathrm{C}$ until analysis. Concentrations of PRL in plasma were determined by radioimmunoassay (Miller et al., 2000).

\section{Mammary Tissue Samples}

Mammary biopsies were collected at dry off, -20 $\mathrm{d}$ relative to expected calving, 2 and $20 \mathrm{~d}$ relative to actual calving from a subset of animals $(\mathrm{n}=14,7$ cows per treatment). The actual biopsy dates were $-39 \pm$ $1.8,-16 \pm 1.5,3 \pm 0.3$, and $20 \pm 0.4$ d relative to calving. At the time of biopsy, all of the mammary gland quarters biopsied were healthy and had no indication of mastitis. The biopsy procedure was based on the method reported by Farr et al. (1996). The right rear quarter of the cow was biopsied at dry off and 2 d relative to calving, and the left rear quarter was biopsied at -20 and $20 \mathrm{~d}$ relative to calving. Before biopsies, cows were sedated by i.v. injection of xylazine HCL (35 $\mu \mathrm{g} / \mathrm{kg}$ of BW; Pro Labs Ltd., St. Joseph, MO). The biopsied region in the middle of the udder was shaved and sanitized 3 times by scrubbing with iodine scrub, followed by rinsing with $70 \%$ ethanol. Subcutaneous injection of $3 \mathrm{~mL}$ of lidocaine HCL (Phoenix Pharmaceuticals Inc., Burlingame, CA) was administered in a line block above the biopsy site for local anesthesia. A 3 to $4-\mathrm{cm}$ incision was made through the skin and connective tissue, taking care to avoid obvious blood vessels. Mammary tissue $(60 \times 4 \mathrm{~mm}$ in diameter $)$ was obtained using a mammary biopsy tool (Farr et al., 1996) with a cordless drill (18V; Black \& Decker, Towson, MD). Incisions were closed by Michel 18-mm stainless steel wound clips and sprayed with antiseptic wound dressing (Blu-Kote; H. W. Naylor Co. Inc., Morris, NY). Biopsied tissue was rinsed with PBS and trimmed of fat. A portion of mammary tissue $(5 \times$ $4 \mathrm{~mm}$ in diameter) was cut for immunohistochemistry analysis and fixed in $10 \%$ neutral formalin for $24 \mathrm{~h}$ at $4^{\circ} \mathrm{C}$, and then transferred to $70 \%$ ethanol for future analysis. Samples were dehydrated and embedded in paraffin (MBI Cell and Tissue Analysis Core, University of Florida, Gainesville) according to the standard protocol and $4-\mu \mathrm{m}$ paraffin tissue sections were collected onto poly-L-lysine-coated slides.

\section{Immunohistochemistry}

Ki67 Antigen Localization. The Ki67 antigen is expressed in the nuclei of proliferating cells (Scholzen and Gerdes, 2000). Mammary tissue sections were deparaffinized in mixed xylenes and hydrated through a graded ethanol series. After quenching in $3 \% \mathrm{H}_{2} \mathrm{O}_{2}$ for 10 min, antigen retrieval was accomplished by microwaving. Slides were microwaved (MA-879MQ, Goldstar Co. Ltd, Seoul, Korea) for $5 \mathrm{~min}$ in a glass slide holder containing $400 \mathrm{~mL}$ of citrate buffer $(10 \mathrm{mM}$, pH 6.0), remained without disturbing for $5 \mathrm{~min}$, and then heated for 5 more min. After microwaving, all slides stayed in 
the slide holder without disturbing for an additional 30 min to cool. Following washes in double-distilled $\mathrm{H}_{2} \mathrm{O}$ and PBS, sections were blocked with $5 \%$ non-immune horse serum to eliminate nonspecific binding. All slides except the negative control slides were incubated with primary antibody (mouse anti-Ki67; Invitrogen Corp., Camarillo, CA) diluted 1:80 in PBS containing 1\% nonimmune horse serum, overnight at $4^{\circ} \mathrm{C}$. After washing with PBS, slides were incubated with goat anti-mouse horseradish peroxidase (SuperPicture kit; Invitrogen Corp.) for $30 \mathrm{~min}$ at $25^{\circ} \mathrm{C}$, followed by extensive washing in PBS. Immune complexes were visualized colorimetrically with $3,3^{\prime}$-diaminobenzidine (Invitrogen Corp.) and counterstained with hematoxylin (Invitrogen Corp.). Slides were dehydrated through a graded ethanol series and mixed xylenes, and mounted with Histomount (Invitrogen Corp.).

Terminal Deoxynucleotidyl Transferase Deoxyuridine Triphosphate Nick-End Labeling. After deparaffinization and hydration, samples were digested with $20 \mu \mathrm{L} / \mathrm{mL}$ of proteinase $\mathrm{K}$ (Ambion; Applied Biosystems Inc., Austin, TX) for $8 \mathrm{~min}$ at room temperature, followed by washing with double-distilled $\mathrm{H}_{2} \mathrm{O}$. Endogenous peroxidase activity was quenched by incubation with $2 \% \mathrm{H}_{2} \mathrm{O}_{2}$ in PBS for 10 min. Following incubation in equilibration buffer (ApopTag Plus Peroxidase In Situ Apoptosis kit; Millipore, Billerica, MA) for $10 \mathrm{~min}$, sections were incubated with terminal deoxynucleotidyl transferase (333 units $/ \mathrm{mL})$ and digoxigenin-conjugated nucleotides (Millipore) for 60 min at $37^{\circ} \mathrm{C}$. Reactions were stopped and washed extensively with PBS. Labeled DNA was detected with anti-digoxigenin-peroxidase (ApopTag Plus Peroxidase in situ Apoptosis kit, Millipore) for $30 \mathrm{~min}$ at $25^{\circ} \mathrm{C}$ followed by colorimetric detection with 3,3'-Diaminobenzidine. Sections were counterstained with methyl green, dehydrated and mounted.

\section{Quantification of Immunohistochemistry Slides}

Tissue sections were viewed using a light microscope (Nikon Corp., Tokyo, Japan) to quantify Ki67 antigen or terminal deoxynucleotidyl transferase deoxyuridine triphosphate nick-end labeling-labeled cells. One section per cow at each time point was evaluated. For each section, 5 fields were randomly selected and quantified. At least 2,000 cells were counted in each section. Cell types were classified based on the mammary gland structure. Epithelial cells represent cells inside the basement membranes of alveoli, including secretory epithelial cells, myoepithelial cells, and leukocytes. Stromal cells were defined as cells in the connective tissue, including the fibroblasts, adipocytes, endothelial cells, and blood cells. Total cells represent all the cells included in a field. The percentage of labeled cells to all the cells within each cell type was calculated as proliferation or apoptotic rate.

\section{Statistical Analysis}

The means \pm standard error of the means of pen THI, water intake, and biopsy date were calculated using PROC UNIVARIATE of SAS 9.2 (SAS Institute Inc., Cary, NC). Parity, dry period length, gestation length, and calf weight were analyzed using PROC GLM of SAS 9.2 and least squares means \pm standard error of the means are presented. The repeated measurement procedure of PROC MIXED of SAS 9.2 was used to analyze milk production, milk composition, rectal temperature, respiration rate, cumulative BW change, cumulative BCS change, DMI, and PRL concentration, and the least squares means \pm standard error of the means are reported; the statistical model includes treatment, time, and treatment by time, with cow(treatment) as random effect. In addition, data from cumulative BW change, cumulative BCS change, and DMI were split into prepartum and postpartum periods (i.e., treatment and post-treatment) and analyzed separately. To avoid the variation of BW on DMI, the BW at dry off and calving were included in the SAS model as covariates to analyze the DMI during the prepartum and postpartum periods, respectively. For circulating PRL analysis, the samples taken at dry off were considered as covariates and included in the SAS model. Data from immunohistochemistry assays were analyzed by PROC GLIMMIX of SAS 9.2 using a generalized linear mixed model based on the binomial distribution with a logit link function and least squares means \pm standard error of the means are reported. For the variables mammary cell proliferation and apoptotic rate, the value at dry off were considered as baseline and included in the SAS model as covariates. Because the effect of the covariate was not significant $(P>$ 0.25 ), the covariate was removed from the SAS model in the mammary apoptotic rate analysis.

\section{RESULTS}

\section{Dry Period Length, THI, Rectal Temperature, Respiration Rate, and Calf Weight}

Pens for HT and CL cows had similar THI (Table 2) during the dry period, which was expected because the cooling system in the current experiment was designed to cool the animals and not the environment. During the dry period, cows exposed to cooling had lower rectal temperatures in the morning $(P<0.001$; Table 2$)$ and afternoon $(P<0.001$; Table 2$)$ and a lower respiration 
Table 2. Temperature-humidity index (THI) of the pens, dry period length, gestation length, rectal temperatures, respiration rate, and calf weight of cows exposed to either heat stress $(\mathrm{n}=15)$ or cooling $(\mathrm{n}=$ 14) during the dry period

\begin{tabular}{|c|c|c|c|c|}
\hline \multirow[b]{2}{*}{ Variable } & \multicolumn{2}{|c|}{ Treatment } & \multirow[b]{2}{*}{ SEM } & \multirow[b]{2}{*}{$P$-value } \\
\hline & Heat stress & Cooling & & \\
\hline Pen THI & 76.59 & 76.62 & 0.10 & - \\
\hline Dry period length, $\mathrm{d}$ & 38.93 & 42.21 & 1.47 & 0.13 \\
\hline Gestation length, d & 274.1 & 277.4 & 1.34 & 0.10 \\
\hline Rectal temperature a.m., ${ }^{\circ} \mathrm{C}$ & 38.81 & 38.60 & 0.03 & $<0.001$ \\
\hline Rectal temperature p.m., ${ }^{\circ} \mathrm{C}$ & 39.40 & 39.04 & 0.04 & $<0.001$ \\
\hline Respiration rate, breaths/min & 78.36 & 45.59 & 2.14 & $<0.001$ \\
\hline Calf weight, $\mathrm{kg}$ & 41.63 & 46.45 & 1.33 & 0.01 \\
\hline
\end{tabular}

rate $(P<0.001$; Table 2$)$ relative to cows in heat stress. Compared with CL cows, HT cows tended to have a shorter dry period and gestation length $(P=0.13$ and $P=0.10$, respectively; Table 2$)$. In addition, the calves from CL cows were heavier than those from HT cows at birth $(P=0.01$; Table 2$)$.

\section{Production Measurements, BW, BCS, DMI, and PRL}

Heat stress during the dry period decreased milk production compared with cooling $(P<0.03$; Figure 1). Until 40 wk postpartum, CL cows produced $5 \mathrm{~kg} / \mathrm{d}$ more milk relative to HT cows. No treatment effects on milk fat and lactose concentration $(P=0.57$ and $P=0.28$, respectively; Table 3 ) were observed until 40 wk postpartum, and, relative to HT cows, CL cows produced more milk lactose $(P=0.02$; Table 3$)$ and tended to produce more milk fat $(P=0.06$; Table 3$)$ as expected with the higher milk yield. Both groups had similar milk protein yield $(P=0.17$; Table 3$)$, even though CL cows have lower milk protein concentration

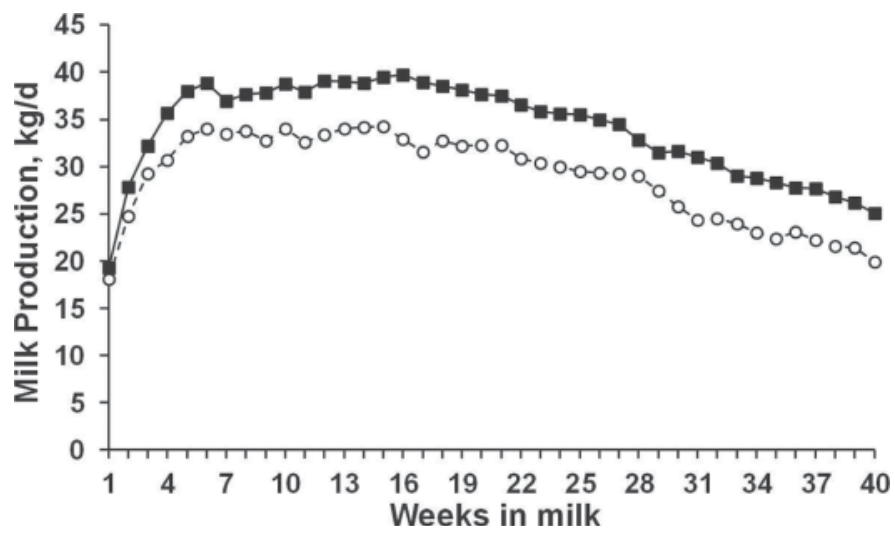

Figure 1. Effect of heat stress $(\mathrm{n}=15)$ and cooling $(\mathrm{n}=14)$ during the dry period on milk production in the subsequent lactation. Solid squares (ם) and open circles $(\bigcirc)$ represent cooling and heat stress, respectively. All cows were managed and housed as one group following parturition. Cows exposed to cooling during the dry period produced more milk compared with cows in heat stress up to $40 \mathrm{wk}$ in milk $(33.9 \pm 1.6$ vs. $28.9 \pm 1.5 \mathrm{~kg} / \mathrm{d}$, respectively; $P<0.03)$.
$(P=0.01 ;$ Table 3$)$ compared with HT cows. Interestingly, CL cows tended to have lower SCS compared with HT cows $(P=0.10$; Table 3$)$.

Heat stress during the dry period decreased DMI of the cows prepartum $(P<0.02$; Figure 2$)$ compared with cooling, but not postpartum $(P=0.70$; Figure 2$)$. In addition, a tendency of treatment by time interaction was observed $(P<0.08$; Figure 2$)$, such that CL cows tended to eat more as the lactation advanced. During the prepartum period, HT cows gained less weight than CL cows $(P=0.05$; Table 3$)$, but losses were not different after calving $(P=0.29$; Table 3$)$. Both groups had similar BCS change in the dry period $(P=0.4$; Table 3) and postpartum period $(P=0.15$; Table 3$)$. Compared with cows in CL, cows exposed to HT had

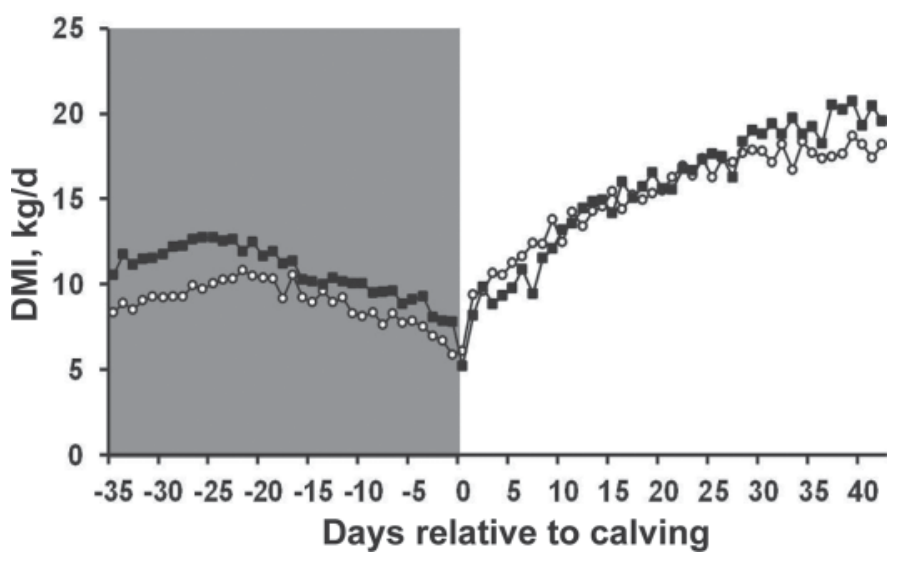

Figure 2. Effect of heat stress $(\mathrm{HT}, \mathrm{n}=15)$ and cooling $(\mathrm{CL}, \mathrm{n}$ $=14$ ) during the dry period on the DMI from -35 to $42 \mathrm{~d}$ relative to calving. Solid squares $(\mathbf{\square})$ and open circles $(\bigcirc)$ represent cooling (CL) and heat-stress (HT) treatment, respectively. Data were split into prepartum and postpartum and analyzed separately. Body weight at dry off and calving were included in the SAS (SAS Institute Inc., Cary, NC) model as covariate during the prepartum and postpartum period, respectively. The CL cows had higher DMI during the prepartum period compared with HT cows $(10.6 \pm 0.5$ vs. $8.9 \pm 0.5 \mathrm{~kg} / \mathrm{d}$, respectively; $P<0.02)$. During the postpartum period, no difference was observed between $\mathrm{CL}$ cows and $\mathrm{HT}$ cows $(15.8 \pm 0.7$ vs. $15.4 \pm$ $0.7 \mathrm{~kg} / \mathrm{d}$, respectively; $P=0.7)$; however, a tendency of treatment by time difference was observed $(P<0.08)$. 


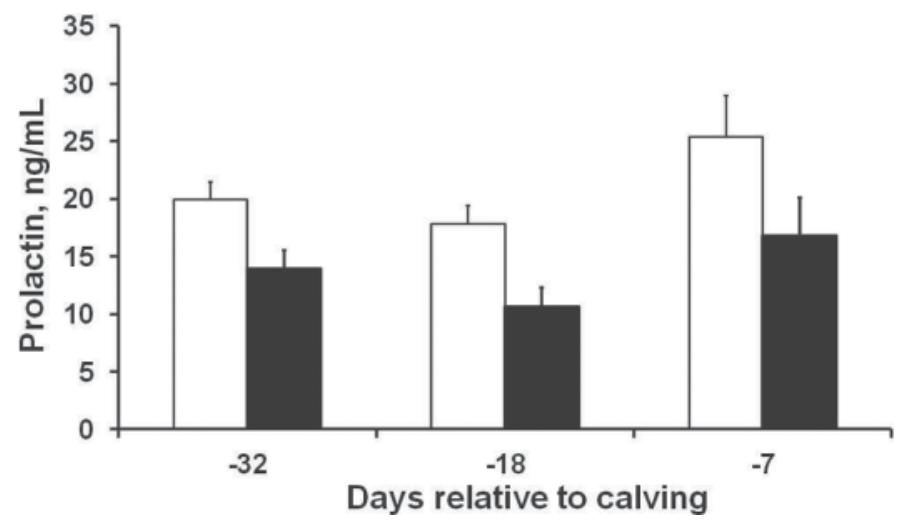

Figure 3. Effect of heat stress $(\mathrm{n}=15)$ and cooling $(\mathrm{n}=14)$ during the dry period on the prolactin concentration of plasma. Solid bars represent cows exposed to cooling and open bars represent cows in heat stress. Prolactin concentrations of plasma at dry off were included in the SAS (SAS Institute Inc., Cary, NC) model as covariates. Heat-stressed cows had increased prolactin concentration of plasma compared with cooled cows $(21.04 \pm 1.6$ vs. $13.78 \pm 1.5 \mathrm{ng} / \mathrm{mL}$, respectively; $P<0.01)$.

increased circulating PRL during the dry period $(P<$ 0.01 ; Figure 3).

\section{Mammary Cell Proliferation and Apoptosis}

Compared with cooling, heat stress tended to decrease mammary epithelial cell proliferation rate (dry off as covariate, $P<0.1$; Figure 4 ) but did not affect mammary stromal cell proliferation rate (dry off as covariate, $P=0.56$; Figure 4 ), as measured by Ki67 antigen labeling. A tendency of treatment by day interaction for mammary total cell proliferation rate (dry off as covariate, $P=0.13$; Figure 4 ) was observed, such that HT cows had lower total mammary cell proliferation rate at $-20 \mathrm{~d}$ relative to calving compared with CL (dry off as covariate, $P=0.06$; Figure 4 ). In addition, relative to the postpartum period, mammary epithelial, stromal, and total cells had higher proliferation rate at $-20 \mathrm{~d}$ relative to calving (dry off as covariate, $P<$ $0.01, P<0.01$, and $P<0.01$ respectively; Figure 4 ).

Heat stress during the dry period did not affect mammary epithelial, stromal, and total cell rate of apoptosis $(P=0.9, P=0.64$, and $P=0.83$, respectively; Figure 5) compared with heat stress abatement. However, mammary epithelial and total cells had a higher rate of apoptosis at $2 \mathrm{~d}$ relative to calving $(P<0.01$ and $P<$ 0.01 , respectively; Figure 5$)$, but no time effect was observed for mammary stromal cells $(P=0.59$; Figure 5$)$.

\section{DISCUSSION}

Observation that THI in the barn where both treatments were housed exceeded 72 indicates that cows were exposed to heat stress (Armstrong, 1994). In addition, decreased rectal temperatures and decreased respiration rate in CL cows suggests that the cooling system in the current experiment effectively alleviated the heat strain on CL cows compared with HT cows.

Table 3. Milk composition, BW, DMI, and water intake of cows exposed to heat stress $(\mathrm{n}=15)$ or cooling (n $=14$ ) during the dry period

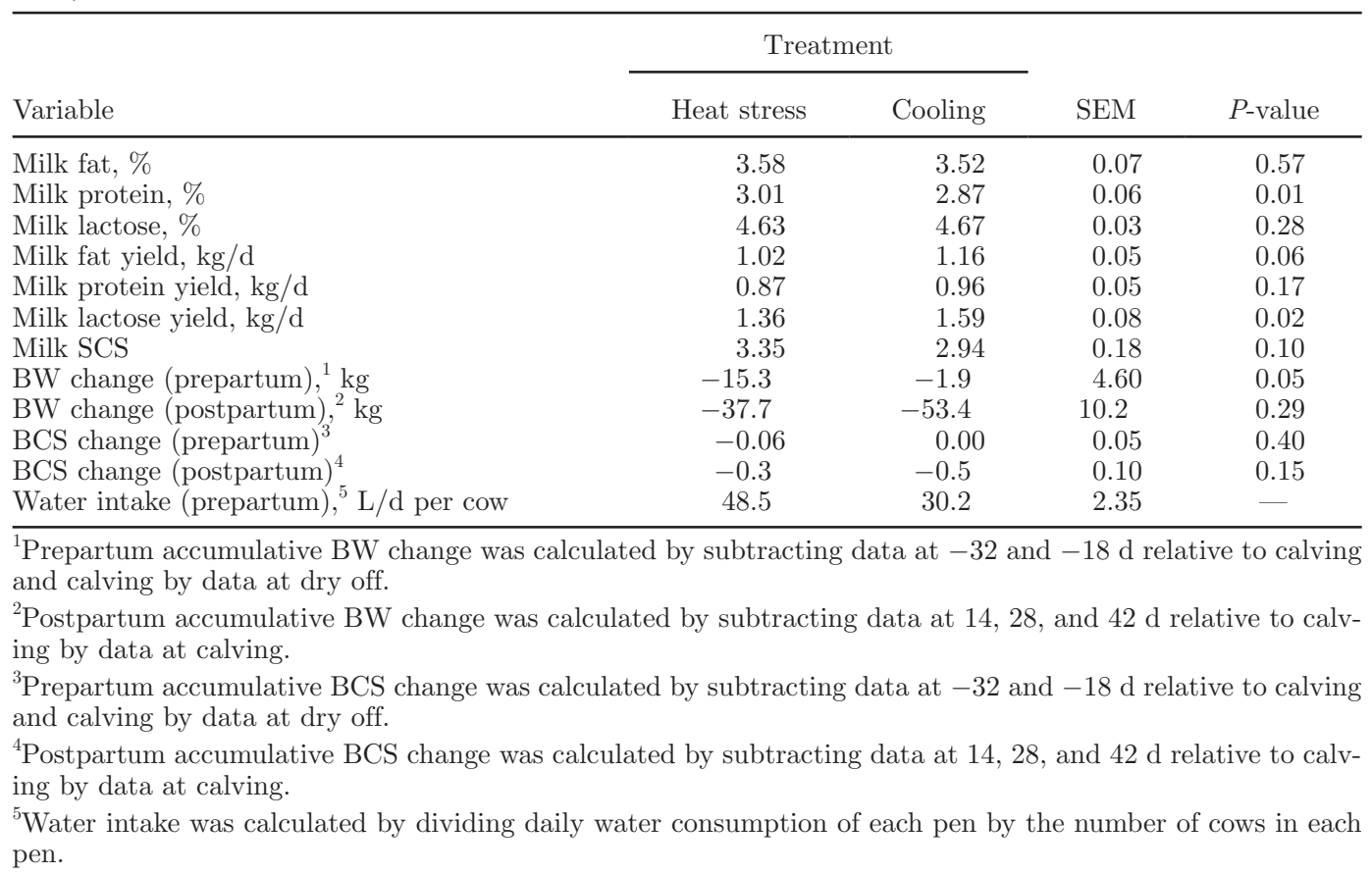



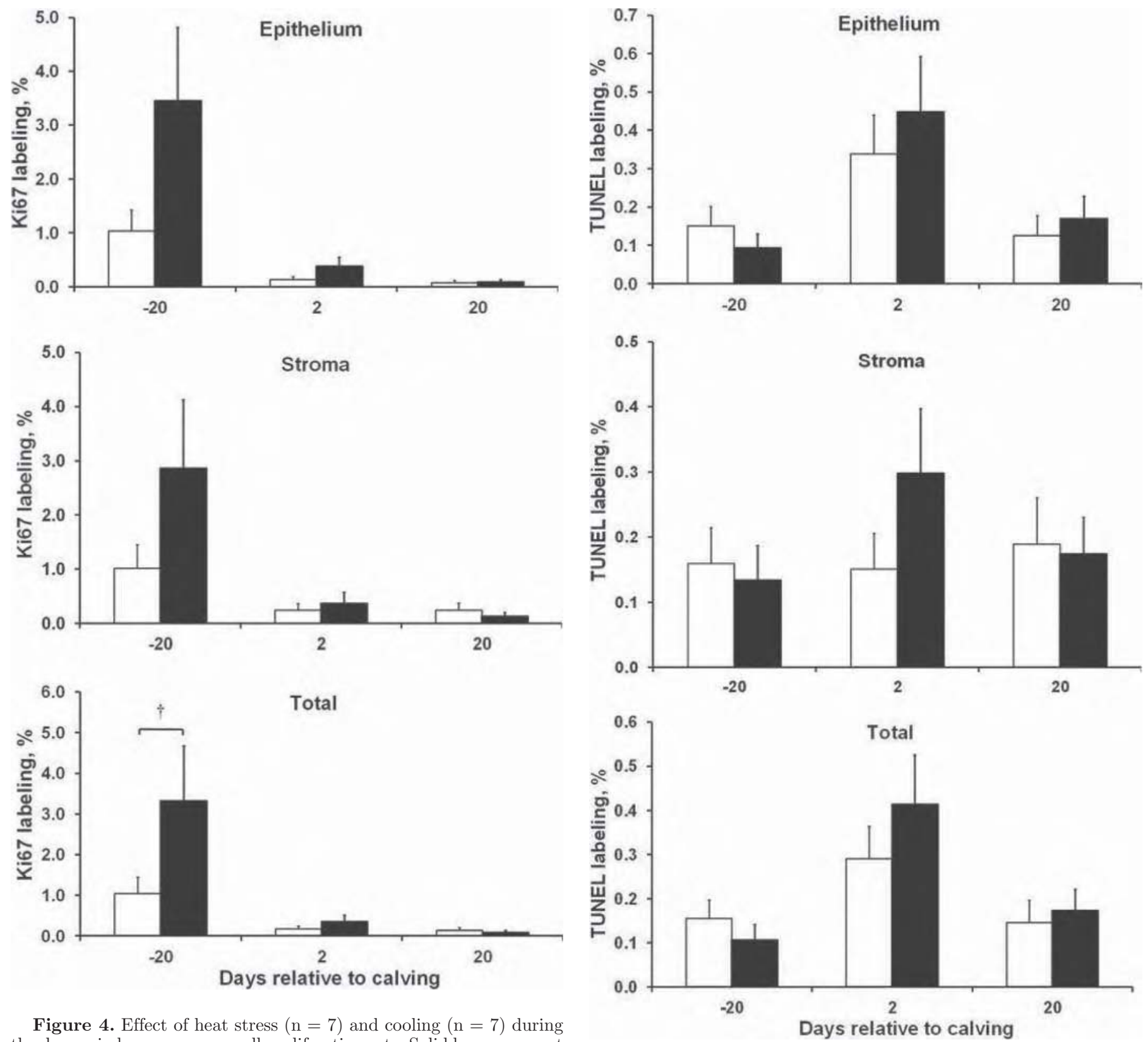

Figure 4 . Effect of heat stress $(n=7)$ and cooling $(n=7)$ during
he cows exposed to cooling and open bars represent cows in heat stress. Mammary cell proliferation rate at dry off was considered as baseline and included in the SAS (SAS Institute Inc., Cary, NC) model as covariate. A tendency of treatment effect existed for epithelial cells (dry off as covariate, $P<0.1$ ), and no treatment effects were observed for stromal and total cells (dry off as covariate, $P=0.56$ and $P=0.31$, respectively). A tendency of treatment by day interaction for total cells (dry off as covariate, $P=0.13$ ) was observed. Time effects were observed for epithelial, stromal, and total cells (dry off as covariate, $P$ $<0.01, P<0.01$, and $P<0.01$, respectively). $\dagger P=0.06$.

Moreover, lower calf weight and decreased BW during the dry period of HT cows provide further evidence that heat stress was present but abated in CL cows relative to HT cows. Similar results have been reported in these indices previously under a variety of housing

Figure 5. Effect of heat stress $(\mathrm{n}=7)$ and cooling $(\mathrm{n}=7)$ during the dry period on mammary cell apoptotic rate determined by terminal deoxynucleotidyl transferase deoxyuridine triphosphate nick-end labeling (TUNEL). No treatment effects of epithelial, stromal, and total cells $(P=0.9, P=0.64$, and $P=0.83$, respectively) occurred. Time effects were observed for both epithelial and total cell apoptotic rate $(P<0.01$ and $P<0.01$, respectively).

conditions (Collier et al., 1982b; Wolfenson et al., 1988; Adin et al., 2009).

Cows exposed to cooling during the dry period produced more milk in the subsequent lactation compared with heat-stressed cows in the postpartum period, consistent with the results from other studies (AvendañoReyes et al., 2006; Adin et al., 2009; do Amaral et 
al., 2009). Similar to other reports (Avendaño-Reyes et al., 2006; do Amaral et al., 2009), milk fat yield was greater in the CL cows compared with HT cows. Yet with regard to milk fat concentration, published results are not consistent. For example, do Amaral et al. (2009, 2011) reported that heat stress during the dry period decreased milk fat concentration in the subsequent lactation, but Adin et al. (2009) did not observe any effect of prepartum cooling. In the current study, heat stress during the dry period did not affect the milk fat concentration in the subsequent lactation. The decrease in milk protein concentration of CL cows was not expected and in contrast with other studies (Adin et al., 2009; do Amaral et al., 2009, 2011). The biological significance of this decrease is unknown, but because of the potential economic impact to the producer, it is of interest for further investigation.

Similar to other reports in the dry period (do Amaral et al., 2009) and lactation (Rhoads et al., 2009), HT cows consumed less DM compared with CL cows during the dry period. Even though no treatment effect on DMI occurred during the postpartum period, a tendency of treatment by time interaction was observed, which indicates that CL cows have higher DMI after 6 wk postpartum compared with HT cows. That may reflect the higher nutrient demand of CL cows relative to HT cows due to greater milk yield between treatments after the peak of lactation. During the dry period, CL cows gained more weight compared with HT cows, which is likely a result of higher DMI in CL cows. Because no difference of BCS change was observed during the prepartum period, the increased BW of CL cows during the dry period may result from higher fetal growth. No significant differences between treatments for BW change and BCS change were observed during the postpartum period, which suggests that both groups of cows had similar adipose tissue mobilization in early lactation. This result is in contrast with those of do Amaral et al. (2009) who reported that cows exposed to cooling during the dry period had greater NEFA concentrations in early lactation relative to cows exposed to heat stress. However, the relatively small number of animals in the current experiment may have resulted in a lack of sensitivity to detect differences of BW and BCS change in early lactation.

Mammary development during the dry period is characterized by increased DNA content (Tucker, 1987) and high cell proliferation (Capuco et al., 1997; Sorensen et al., 2006), which is consistent with the current study in which the mammary cell proliferation rate during the dry period ( $-20 \mathrm{~d}$ relative to calving) was higher than during early lactation $(2$ and $20 \mathrm{~d}$ relative to calving). In addition, the CL cows had higher mammary epithelial cell proliferation rate during the transition period and had higher total cell proliferation rate at -20 d relative to calving relative to HT cows, although no difference was observed for mammary stromal cells. Adin et al. (2009) concluded that cows cooled during the dry period had higher mammary cell proliferation during the close-up period compared with non-cooled cows based on higher gene expression of hormone sensitive lipase in the mammary gland. However, this conclusion is relatively arbitrary because during the last week of pregnancy mammary secretory cell numbers are already increased (Capuco et al., 1997) and different differentiation states between 2 treatments may also account for any difference in gene expression in lipid synthetic pathways. Our observation provides direct evidence that heat stress during the dry period depresses proliferation, and thus, milk yield capacity.

The mechanism that underlies the decrease in mammary cell proliferation during heat stress in the dry period is still unclear. One possibility is disturbed PRL signaling under heat stress, given the critical role of PRL in mammogenesis and lactogenesis in cattle as in other mammals (Tucker, 2000). Effects of PRL are mediated through PRL-R, which belongs to the cytokine receptor superfamily, and PRL-R is expressed in multiple tissues, including the mammary gland (BoleFeysot et al., 1998; Chilton and Hewetson, 2005). An inverse relationship exists between circulating PRL and PRL-R expression such that environmentally induced increases in circulating PRL depress PRL-R expression in multiple tissues. For example, exposure to LDPP increases circulating PRL but PRL-R expression in mammary gland, liver, and lymphocytes is concurrently decreased (Auchtung et al., 2003). Further, the enhanced PRL signaling in the mammary gland of cows exposed to SDPP during the dry period results in increased mammary gland development in the dry period (Wall et al., 2005) and improved lactation performance in the next lactation (Auchtung et al., 2005) compared with cows exposed to LDPP. Heat stress also increases circulating PRL concentrations (Collier et al., 1982a). Moreover, the inverse relationship between blood PRL concentration and PRL-R gene expression in multiple tissues observed under variable photoperiods (Dahl, 2008) also exists in thermally challenged cattle, at least during the dry period. Indeed, do Amaral et al. (2009, 2010) demonstrated that cows exposed to heat stress in the dry period had higher blood PRL concentration and lower PRL-R gene expression in the liver and immune cells compared with cows receiving heat stress abatement. So it is logical to extend this inverse relationship to the mammary gland. In the current study, heat stress also increased circulating PRL compared with cooling, as shown by others (do Amaral et al., 2009, 2010; Collier et al., 1982a). 
Mammary epithelial cells and total cells tended to undergo higher apoptosis at $2 \mathrm{~d}$ compared with $20 \mathrm{~d}$ relative to calving and prepartum period. The higher mammary epithelial cell apoptosis in early lactation is consistent with previous reports (Capuco et al., 2001; Sorensen et al., 2006). However, the mechanism of increased programmed cell death in the early postpartum period is still not well understood. Possible mechanisms include greater leukocyte apoptosis and tissue edema (Capuco et al., 2001) after calving and further elimination of senescent cells from the last lactation or undifferentiated cells from the dry period (Sorensen et al., 2006). No treatment effect was observed for mammary epithelial, stromal, and total cell rate of apoptosis. Wall et al. (2005) reported that SDPP during the dry period tended to decrease mammary epithelial cell apoptosis compared with LDPP, which differs from our findings, even though the effects of photoperiod and heat stress during the dry period are both thought to be mediated by PRL signaling (Dahl, 2008). In addition to the pro-proliferative effect, PRL elicits anti-apoptotic effect in mammary cells of mice (Flint et al., 2001) and cattle (Accorsi et al., 2002). However, other hormonal responses involved in heat stress may also account for modulation of mammary cell apoptosis. For example, progesterone (Roman-Ponce et al., 1981; Collier et al., 1982b) and glucocorticoid (Alvarez and Johnson, 1973; Roman-Ponce et al., 1981; Wise et al., 1988) concentrations increase with heat stress in cattle, and both hormones prevent murine mammary gland involution by decreasing mammary epithelial cell apoptosis (Feng et al., 1995). Possibly, the anti-apoptotic effect of elevated progesterone and cortisol concentrations offset the proapoptotic effect result from decreased PRL signaling in HT cows during the dry period compared with CL cows.

Although the different response of PRL signaling in the mammary gland may be a reasonable mechanism for the observed effects on mammary cell response in the present study, we cannot exclude other possibilities. Indeed, heat stress during the late gestation also increases circulating progesterone and decreases the blood concentration of placenta hormone estrone sulfate relative to cooling (Collier et al., 1982b). It is well known that estrogen is involved in the initiation of lactation and progesterone has a negative effect on lactogenesis (Tucker, 2000), so the increased progesterone and decreased estrone sulfate in heat-stressed cows may suppress mammary epithelial cell differentiation during lactogenesis, which, in turn, results in decreased milk production in the postpartum period. However, Collier et al. (1982b) did not observe significant differences in milk production between the cooled and non-cooled cows during late gestation, so the altered steroid hormones and compromised placental function may not be enough to explain the significant decrease in lactation performance of HT cows in the current study. The other reason for decreased milk production of HT cows may be the shortened gestation length and dry period. It is possible that HT cows missed the critical period for the mammary gland development during the dry period. However, even though 3 to 6 d shorter gestation length by induced parturition decreased milk production in early lactation (Beardsley et al., 1976; Bremmer et al., 1999), calving induction did not affect the milk yield for the whole lactation (Schmitt et al., 1975; Bremmer et al., 1999).

Manipulation of mammary cell number and secretory capacity can affect lactation performance (Capuco et al., 2003). The relative difference between rates of mammary cell proliferation and apoptosis determine the mammary cell number and, thus, cell secretory ability can be increased by enhanced cell renewal (Capuco et al., 2001). Because the dry period has more extensive mammary growth and cell turnover compared with lactation (Capuco et al., 1997; Capuco et al., 2001; Sorensen et al., 2006), this nonlactating period provides an opportune window to manipulate mammary gland development. In the present study, heat stress during the dry period did not affect mammary cell apoptosis, but the higher rate of mammary epithelial cell proliferation of CL cows during the transition period indicates that CL cows have greater mammary growth when dry and enter the next lactation with more mammary epithelial cells relative to HT cows. A greater number of mammary secretory cells in CL cows during lactation are consistent with the higher milk yield of CL cows relative to HT cows. Also, the lactation curves of CL cows and HT cows were separated throughout lactation, which provides further evidence that heat stress during the dry period compromises the lactation performance in the subsequent lactation through a depression of mammary gland functional capacity.

\section{CONCLUSIONS}

Heat stress during the dry period decreased milk production in the subsequent lactation. Compared with CL cows, HT cows had lower mammary epithelial cell proliferation during the transition period, but no differences were observed in mammary stromal cell proliferation and mammary cell apoptosis in the dry period. Therefore, the compromised mammary gland development induced by heat stress in the dry period decreases lactation performance in the next lactation by decreasing mammary cell proliferation. 


\section{ACKNOWLEDGMENTS}

The authors thank the staff of the Dairy Unit at the University of Florida (Hague) for animal care and data collection. The appreciation also extends to A. V. Capuco from the USDA (Beltsville, MD) for his tremendous assistance with the immunohistochemistry assays and to L. J. Young and J. E. P. Santos from the University of Florida for the assistance with statistical analysis.

\section{REFERENCES}

Accorsi, P. A., B. Pacioni, C. Pezzi, M. Forni, D. J. Flint, and E. Seren. 2002. Role of prolactin, growth hormone and insulin-like growth factor 1 in mammary gland involution in the dairy cow. J. Dairy Sci. 85:507-513.

Adin, G., A. Gelman, R. Solomon, I. Flamenbaum, M. Nikbachat, E. Yosef, A. Zenou, A. Shamay, Y. Feuermann, S. J. Mabjeesh, and J. Miron. 2009. Effects of cooling dry cows under heat load conditions on mammary gland enzymatic activity, intake of food water, and performance during the dry period and after parturition. Livest. Sci. 124:189-195.

Alvarez, M. B., and H. D. Johnson. 1973. Environmental heat exposure on cattle plasma catecholamine and glucocorticoids. J. Dairy Sci. 56:189-194.

Armstrong, D. V. 1994. Heat stress interaction with shade and cooling. J. Dairy Sci. 77:2044-2050.

Auchtung, T. L., P. E. Kendall, J. L. Salak-Johnson, T. B. McFadden, and G. E. Dahl. 2003. Photoperiod and bromocriptine treatment effects on expression of prolactin receptor mRNA in bovine liver, mammary gland and peripheral blood lymphocytes. J. Endocrinol. 179:347-356.

Auchtung, T. L., A. G. Rius, P. E. Kendall, T. B. McFadden, and G. E. Dahl. 2005. Effects of photoperiod during the dry period on prolactin, prolactin receptor, and milk production of dairy cows. J. Dairy Sci. 88:121-127.

Auchtung, T. L., J. L. Salak-Johnson, D. E. Morin, C. C. Mallard, and G. E. Dahl. 2004. Effects of photoperiod during the dry period on cellular immune function of dairy cows. J. Dairy Sci. $87: 3683-3689$.

Avendaño-Reyes, L., F. D. Alvarez-Valenzuela, A. Correa-Calderón, J. S. Saucedo-Quintero, P. H. Robinson, and J. G. Fadel. 2006. Effect of cooling Holstein cows during the dry period on postpartum performance under heat stress conditions. Livest. Sci. 281:2535-2547.

Bachman, K. C., and M. L. Schairer. 2003. Bovine studies on optimal lengths of dry period. J. Dairy Sci. 86:3027-3037.

Beardsley, G. L., L. D. Muller, H. A. Garverick, F. C. Ludens, and W. L. Tucker. 1976. Initiation of parturition in dairy cows with dexamethasone. II. Response to dexamethasone in combination with estradiol benzoate. J. Dairy Sci. 59:241-247.

Bole-Feysot, C., V. Goffin, M. Edery, N. Binart, and P. A. Kelly. 1998. Prolactin (PRL) and its receptor: Actions, signal transduction pathways and phenotypes observed in PRL receptor knockout mice. Endocr. Rev. 19:225-268.

Bremmer, D. R., J. O. Christensen, R. R. Grummer, F. E. Rasmussen, and M. C. Wiltbank. 1999. Effects of induced parturition and estradiol on feed intake, liver triglyceride concentration, and plasma metabolites of transition dairy cows. J. Dairy Sci. 82:1440-1448.

Capuco, A. V., R. M. Akers, and J. J. Smith. 1997. Mammary growth in Holstein cows during the dry period: Quantification of nucleic acids and histology. J. Dairy Sci. 80:477-487.

Capuco, A. V., S. E. Ellis, S. A. Hale, E. Long, R. A. Erdman, X. Zhao, and M. J. Paape. 2003. Lactation persistency: Insights from mammary cell proliferation studies. J. Anim. Sci. 81:18-31.

Capuco, A. V., D. L. Wood, R. Baldwin, K. Mcleod, and M. J. Paape, 2001. Mammary cell number, proliferation, and apoptosis during a bovine lactation: Relation to milk production and effect of bST. J. Dairy Sci. 84:2177-2187.

Chilton, B. S., and A. Hewetson. 2005. Prolactin and growth hormone signaling. Curr. Top. Dev. Biol. 68:1-23.

Collier, R. J., D. K. Beede, W. W. Thatcher, L. A. Israel, and C. J. Wilcox. 1982a. Influences of environment and its modification on dairy animal health and production. J. Dairy Sci. 65:2213-2227.

Collier, R. J., G. E. Dahl, and M. J. VanBaale. 2006. Major advances associated with environmental effects on dairy cattle. J. Dairy Sci. 89:1244-1253.

Collier, R. J., S. G. Doelger, H. H. Head, W. W. Thatcher, and C. J. Wilcox. 1982b. Effects of heat stress during pregnancy on maternal hormone concentrations, calf birth weight and postpartum milk yield of Holstein cows. J. Anim. Sci. 54:309-319.

Dahl, G. E. 2008. Effects of short day photoperiod on prolactin signaling in dry cows: A common mechanism among tissues and environments. J. Anim. Sci. 86:10-14.

De Vries, A., M. J. Hayen, E. J. Diepersloot, A. H. Sanders, D. W Webb, and D. R. Bray. 2009. Agreement between fat and protein measurements from DHIA and the AfiLab real time milk analyzer. J. Dairy Sci. 92(Suppl. 1):273 (Abstr.)

Dikmen, S., E. Alava, E. Pontes, J. M. Fear, B. Y. Dikmen, T. A. Olson, and P. J. Hansen. 2008. Differences in thermoregulatory ability between slick-haired and wild-type lactating Holstein cows in response to acute heat stress. J. Dairy Sci. 91:3395-3402.

do Amaral, B. C., E. E. Connor, S. Tao, M. J. Hayen, J. W. Bubolz, and G. E. Dahl. 2009. Heat-stress abatement during the dry period: Does cooling improve transition into lactation? J. Dairy Sci. 92:5988-5999.

do Amaral, B. C., E. E. Connor, S. Tao, M. J. Hayen, J. W. Bubolz, and G. E. Dahl. 2010. Heat stress abatement during the dry period influences prolactin signaling in lymphocytes. Domest. Anim. Endocrinol. 38:38-45.

do Amaral, B. C., E. E. Connor, S. Tao, M. J. Hayen, J. W. Bubolz, and G. E. Dahl. 2011. Heat stress abatement during the dry period influences metabolic gene expression and improves immune status in the transition period of dairy cows. J. Dairy Sci. 94:86-96.

Farr, V. C., K. Stelwagen, L. R. Cate, A. J. Molenaar, T. B. McFadden, and S. R. Davis. 1996. An improved method for the routine biopsy of bovine mammary tissue. J. Dairy Sci. 79:543-549.

Feng, Z., A. Marti, B. Jehn, H. J. Altermatt, G. Chicaiza, and R. Jaggi. 1995. Glucocorticoid and progesterone inhibit involution and programmed cell death in the mouse mammary gland. J. Cell Biol. 131:1095-1103.

Flint, D. J., E. Tonner, C. H. Knight, C. B. A. Whitelaw, J. Webster, M. Barber, and G. Allan. 2001. Control of mammary involution by insulin-like growth factor binding proteins: Role of prolactin. Livest. Prod. Sci. 70:115-120.

Grummer, R. R., and R. R. Rastani. 2004. Why reevaluate dry period length? J. Dairy Sci. 87(E. Suppl.):E77-E85.

Miller, A. R. E., R. A. Erdman, L. W. Douglass, and G. E. Dahl. 2000. Effects of photoperiodic manipulation during the dry period of dairy cows. J. Dairy Sci. 83:962-967.

Rhoads, M. L., R. P. Rhoads, M. J. VanBaale, R. J. Collier, S. R Sanders, W. J. Weber, B. A. Crooker, and L. H. Baumgard. 2009. Effects of heat stress and plane of nutrition on lactating Holstein cows: 1. Production, metabolism, and aspects of circulating somatotropin. J. Dairy Sci. 92:1986-1997.

Roman-Ponce, H., W. W. Thatcher, and C. J. Wilcox. 1981. Hormonal interrelationships and physiological responses of lactating dairy cows to a shade management system in a subtropical environment. Theriogenology 16:139-154.

Schmitt, D., H. A. Garverick, E. C. Mather, J. D. Sikes, B. N. Day, and R. E. Erb. 1975. Induction of parturition in dairy cattle with dexamethasone and estradiol benzoate. J. Anim. Sci. 40:261-268.

Scholzen, T., and J. Gerdes. 2000. The Ki-67 protein: From the known and the unknown. J. Cell. Physiol. 182:311-322.

Sorensen, M. T., J. V. Nørgaard, P. K. Theil, M. Vestergaard, and K. Sejrsen. 2006. Cell turnover and activity in mammary tissue during lactation and dry period in dairy cows. J. Dairy Sci. 89:46324639 . 
Tucker, H. A. 1987. Quantitative estimates of mammary growth during various physiological states: A review. J. Dairy Sci. 70:1958-1966.

Tucker, H. A. 2000. Hormones, mammary growth, and lactation: A 41-year perspective. J. Dairy Sci. 83:874-884.

Wall, E. H., T. L. Auchtung, G. E. Dahl, S. E. Ellis, and T. B. McFadden. 2005. Exposure to short day photoperiod during the dry period enhances mammary growth in dairy cows. J. Dairy Sci. 88:1994-2003
West, J. W. 2003. Effects of heat-stress on production in dairy cattle. J. Dairy Sci. 86:2131-2144

Wise, M. E., D. V. Armstrong, J. T. Huber, R. Hunter, and F. Wiersma. 1988. Hormonal alterations in the lactating dairy cow in response to thermal stress. J. Dairy Sci. 71:2480-2485.

Wolfenson, D., I. Flamenbaum, and A. Berman. 1988. Dry period heat stress relief effects on prepartum progesterone, calf birth weight, and milk production. J. Dairy Sci. 71:809-818 